Short Note

\title{
Improved Synthesis and Determination of the Biologically Active Diastereomer of YK11
}

\author{
Yuichiro Kanno®, Taichi Kusakabe, Nao Saito, Shoko Kikkawa®, Keisuke Takahashi, \\ Isao Azumaya, Kiyomitsu Nemoto *(D) and Keisuke Kato *
}

Faculty of Pharmaceutical Sciences, Toho University, 2-2-1 Miyama, Funabashi, Chiba 274-8510, Japan; ykanno@phar.toho-u.ac.jp (Y.K.); taichi.kusakabe@phar.toho-u.ac.jp (T.K.); 3017004s@st.toho-u.ac.jp (N.S.); s_kikkawa@phar.toho-u.ac.jp (S.K.); keisuke.takahashi@phar.toho-u.ac.jp (K.T.); isao.azumaya@phar.toho-u.ac.jp (I.A.)

* Correspondence: kiyomitsu.nemoto@phar.toho-u.ac.jp (K.N.); kkk@phar.toho-u.ac.jp (K.K.)

Received: 8 April 2020; Accepted: 20 April 2020; Published: 21 April 2020

\begin{abstract}
The palladium catalyzed carbonylation of $\mathbf{1}$ using the chiral ligand $\mathbf{L} \mathbf{1}$ afforded $\mathbf{2}$ in a highly diastereoselective manner. The stereochemistry of the major diastereomer $2 \mathbf{a}$ was determined by $X$-ray crystallographic analysis. AR luciferase reporter assay studies suggested that $2 \mathbf{a}$ was the active constituent of YK11 (2).
\end{abstract}

Keywords: YK11; SARMs; palladium; carbonylation; orthoester

\section{Introduction}

Selective androgen receptor modulators (SARMs) are a class of androgen receptor (AR) ligands that show tissue-selective activation of androgenic signaling [1]. SARMs possess the beneficial effect of androgens with few adverse side effects via androgen receptors [2]. The synthetic steroid $(17 \alpha, 20 E)-17,20-[(1-m e t h o x y e t h y l i d e n e)$ bis(oxy)]-3-oxo-19-norpregna-4,20-diene-21-carboxylic acid methyl ester (YK11) (2) is a type of SARM that partially activates ARs without the amino $\left(\mathrm{NH}_{2}\right)$ and carboxyl- terminal (N/C) interactions [3]. In addition, 2 shows AR-mediated gene-selective transactivation in the AR-positive human breast cancer cell line MDA-MB 453 [3,4]. YK11 is a mixture of two diastereomers $(5: 1)$, and the stereochemistry of the orthoester moiety positioned at the D-ring has not been determined yet. Previously, we reported the synthesis of 2 and related steroids having spiro-orthoester structures [3,5]. $\mathrm{PdCl}_{2}\left(\mathrm{CH}_{3} \mathrm{CN}\right)_{2}$ catalyzed carbonylation of $\mathbf{1}$ in the presence of $p$-benzoquinone in methanol afforded 2 as a 5:1 mixture of diastereomers in $43 \%$ yield (Scheme 1 ). We could not separate these diastereomers because they had the same Rf value in a particular solvent system. Recently, we reported the asymmetric cyclization carbonylation of propargyl acetate using a $\mathrm{Pd}(\mathrm{tfa})_{2} /$ sulfoxide-oxazoline (sox) catalyst, which improved the yield and enantioselectivity [6]. In addition, we reported that DMSO/MeOH solvent is effective for methanolysis of the acylpalladium species [7]. On the basis of these recent findings, we report here the improved synthesis of 2 and elucidation of the stereochemistry of the biologically active diastereomer of 2. 


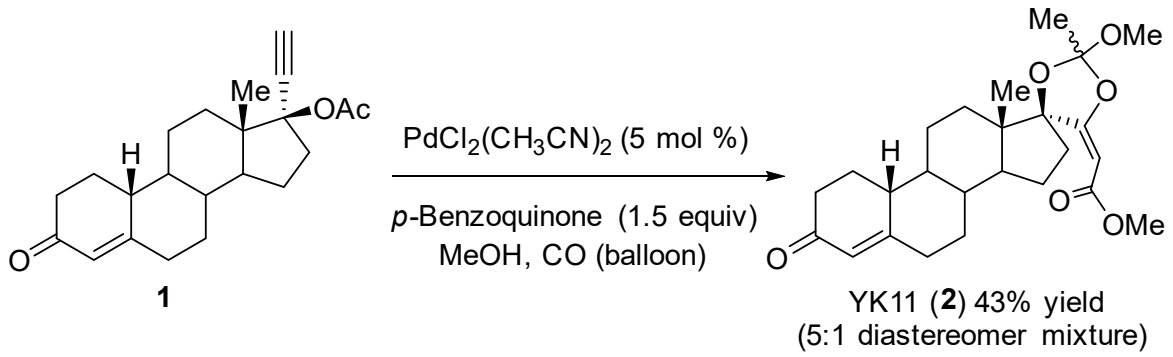

Scheme 1. Previous work: synthesis of YK11 as a 5:1 mixture of diastereomers.

\section{Results and Discussion}

$\operatorname{Pd}(\mathrm{tfa})_{2} / \mathbf{L} \mathbf{1}$ catalyzed carbonylation of $\mathbf{1}$ in the presence of $p$-benzoquinone in methanol afforded 2 as a $4: 1$ mixture of diastereomers in $63 \%$ yield (Table 1 , entry 1$) . \operatorname{Pd}(\mathrm{tfa})_{2} / \mathbf{L} 2$ catalyst gave a complex mixture (Table 1, entry 2). Quinolone-sulfoxide L3 reduced the yield (Table 1, entry 3). The use of $\mathrm{Pd}(\mathrm{tfa})_{2} / \mathbf{L 1}$ catalyst and $\mathrm{DMSO} / \mathrm{MeOH}$ solvent increased the yield and diastereoselectivity (Table 1, entry 4). Lower temperature $\left(-10^{\circ} \mathrm{C}\right)$ improved the diastereoselectivity further and 2 was obtained in the $74 \%$ yield (12:1) (Table 1, entry 5). Separation using column chromatography and recrystallization gave the major diastereomer $2 \mathbf{a}$ in pure form. The structure of $2 \mathbf{a}$ was determined by X-ray crystallographic analysis [8] (Figure 1, Figure S1).

Table 1. Palladium catalyzed cyclization carbonylation of $\mathbf{1}$.
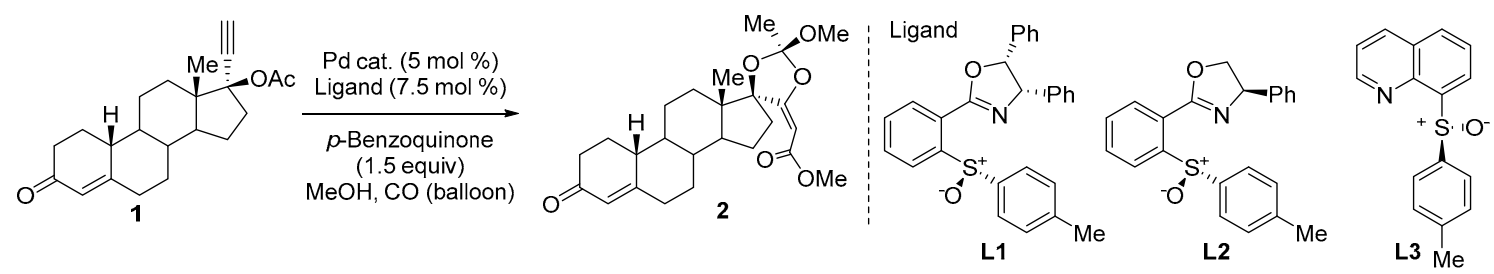

\begin{tabular}{cccccc}
\hline Entry & Ligand & Temp. & Time & Yield (\%) of 2 & dr \\
\hline 1 & L1 & 0 & 36 & 63 & $4: 1$ \\
2 & L2 & 0 & 108 & Complexmixture & - \\
3 & L3 & 25 & 36 & 25 & $4: 1$ \\
$4^{\text {a }}$ & L1 & 0 & 18 & 73 & $7: 1$ \\
$5^{\text {a }}$ & L1 & -10 & 48 & 74 & $12: 1$ \\
\hline
\end{tabular}

${ }^{\mathrm{a}} \mathrm{MeOH} / \mathrm{DMSO}=10 / 1$ was used as solvent.

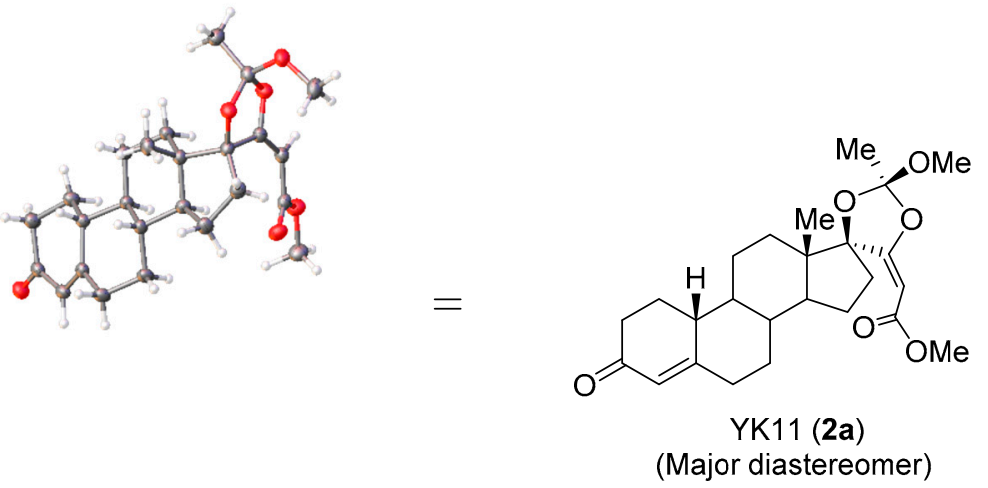

Figure 1. Crystallographic structure of major diastereomer 2a. Colors of atoms: C, gray spheres; $\mathrm{O}$, red spheres; $\mathrm{H}$, light gray spheres.

Next, we performed an ARE-luciferase reporter assay in HEK293 cells to compare the partial agonistic activity of major diastereomer $\mathbf{2 a}$ and the 5:1 mixture of diastereomers $\mathbf{2}$. HEK293 cells were 
transfected with an expression plasmid for AR $(0.05 \mu \mathrm{g})$, ARE-driven luciferase reporter plasmid $(0.1 \mu \mathrm{g})$, and pGL4.74 Renilla reporter plasmid $(0.01 \mu \mathrm{g})$. The cells were treated with the major diastereomer YK11 (2a) or the 5:1 diastereomixture YK11 (2) $(1,2.5,5,7.5,10,25,50,75,100,500 \mathrm{nM})$ for $24 \mathrm{~h}$, and the luciferase activity was measured. The results are shown as the Renilla-normalized luciferase activity and analyzed using KaleidaGraph (Synergy Software). The concentrations of the half maximal ARE activity of 2 and 2a were 12.5 and $7.85 \mathrm{nM}$, respectively (Figure 2). This result suggests that the major diastereomer $\mathbf{2 a}$ is the active constituent of YK11.

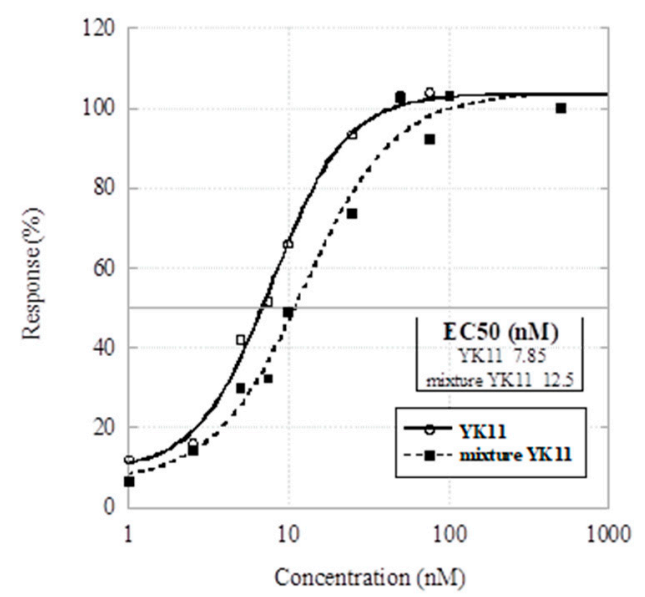

Figure 2. Dose-response curves and EC50 values of YK11 (2a) and mixture YK11 (2). The experiments were performed in three independent wells $(n=4)$ and repeated at least twice.

\section{Materials and Methods}

\subsection{General Information}

All melting points were determined on a microscopic melting point apparatus and are uncorrected. ${ }^{1} \mathrm{H}$ NMR and ${ }^{13} \mathrm{C}$ NMR spectra were recorded at $400 \mathrm{MHz}\left({ }^{1} \mathrm{H}\right.$ NMR) and $100 \mathrm{MHz}\left({ }^{13} \mathrm{C}\right.$ NMR) using $\mathrm{CDCl}_{3}$ as the solvent and TMS as the internal standard. Coupling constants $(J)$ are reported in Hertz $(\mathrm{Hz})$, and spin multiplicities are represented by the following symbols: s (singlet), br-s (broad singlet), $\mathrm{d}$ (doublet), br-d (broad doublet), $\mathrm{t}$ (triplet), q (quartet), sext (sextet) and $\mathrm{m}$ (multiplet). High-resolution mass spectra were obtained using high-resolution EI (double focusing) mass spectrometers. Infrared spectra (IR) were recorded on a FT-IR spectrophotometer and are reported as wavelength numbers $\left(\mathrm{cm}^{-1}\right)$. Column conditions are reported in the experimental section below. All reagents were purchased from commercial sources and used without purification. All evaporations were performed under reduced pressure. Column chromatography was performed using silica gel (particle size 100-210 mm (regular), 40-50 mm (flash)).

\subsection{Synthesis of $\mathbf{L} \mathbf{1}-\mathbf{L} \mathbf{3}$}

L1-L3 were prepared from corresponding aryl bromide and sulfinate as previously described [6].

L1: Eluent: Hexane/AcOEt $=3 / 1$; white solid; $30 \%$ yield; $\mathrm{Mp} 126-127{ }^{\circ} \mathrm{C}$; $[\alpha]_{\mathrm{D}}^{25}=-220.9\left(\mathrm{c} 0.51 \mathrm{CHCl}_{3}\right)$; spectral data were identical with those reported in the literature [6].

L2: Eluent: Hexane/AcOEt $=2 / 1$; pale yellow oil; $48 \%$ yield; $[\alpha]_{\mathrm{D}}^{25}=-327.6\left(\mathrm{c} 0.53 \mathrm{CHCl}_{3}\right)$; spectral data were identical with those reported in the literature [9].

L3: Eluent: Hexane/AcOEt $=2 / 1$; pale yellow solid; $54 \%$ yield; $\mathrm{Mp} 117-119{ }^{\circ} \mathrm{C}$; $[\alpha]_{\mathrm{D}}^{25}=-426.7\left(\mathrm{c} 0.52 \mathrm{CHCl}_{3}\right) ;{ }^{1} \mathrm{H}$ NMR $\left(\mathrm{CDCl}_{3}\right) \delta 2.29(3 \mathrm{H}, \mathrm{s}), 7.15(2 \mathrm{H}, \mathrm{d}, J=8.0 \mathrm{~Hz}), 7.43(1 \mathrm{H}, \mathrm{dd}$, $J=8.4,4.0 \mathrm{~Hz}), 7.73(1 \mathrm{H}, \mathrm{dd}, J=8.4,7.2 \mathrm{~Hz}), 7.81(2 \mathrm{H}, \mathrm{d}, J=8.0 \mathrm{~Hz}), 7.88(1 \mathrm{H}, \mathrm{dd}, J=8.0,1.2 \mathrm{~Hz})$, $8.15(1 \mathrm{H}, \mathrm{dd}, J=8.4,1.6 \mathrm{~Hz}), 8.43(1 \mathrm{H}, \mathrm{dd}, J=7.2,1.6 \mathrm{~Hz}), 8.90(1 \mathrm{H}, \mathrm{dd}, J=4.0,1.6 \mathrm{~Hz}) ;{ }^{13} \mathrm{C}\left\{{ }^{1} \mathrm{H}\right\} \mathrm{NMR}$ $\left(\mathrm{CDCl}_{3}\right) \delta 21.3,122.0,125.1,125.6(2 \mathrm{C}), 126.7,128.3,129.5$ (2C), 130.3, 136.1, 141.1, 142.7, 143.7, 144.1, 
150.1; IR (KBr): $3036,1599,1488,1390,1036,821,789 \mathrm{~cm}^{-1}$; HRMS (EI) $\mathrm{m} / z$ : [M + ] calcd for $\mathrm{C}_{16} \mathrm{H}_{13} \mathrm{NOS}$ 267.0718; found: 267.0717 .

\subsection{Synthesis of YK11 (2a)}

A $100 \mathrm{~mL}$ two-necked round-bottomed flask, containing a magnetic stirring bar, $\mathbf{1}(1.34 \mathrm{~g}, 3.9 \mathrm{mmol})$, p-benzoquinone $(649 \mathrm{mg}, 6.0 \mathrm{mmol})$ and $\mathrm{MeOH} / \mathrm{DMSO}=10 / 1(45 \mathrm{~mL})$ was fitted with a rubber septum and a three-way stopcock connected to a balloon filled with carbon monoxide. The apparatus was purged with carbon monoxide by pumping-filling via the three-way stopcock. A mixture of $\mathrm{Pd}(\mathrm{tfa})_{2}$ $(66.5 \mathrm{mg}, 0.20 \mathrm{mmol})$ and $\mathbf{L 1}(131 \mathrm{mg}, 0.30 \mathrm{mmol})$ in $\mathrm{MeOH} / \mathrm{DMSO}=10 / 1(10 \mathrm{~mL})$ was added dropwise to the stirred solution via a syringe at $-10^{\circ} \mathrm{C}$. After stirring for $48 \mathrm{~h}$ at the same temperature, the mixture was diluted with $\mathrm{CH}_{2} \mathrm{Cl}_{2}(150 \mathrm{~mL})$, washed with $5 \%$ aq. $\mathrm{NaOH}(100 \mathrm{~mL})$, and dried over $\mathrm{MgSO}_{4}$. The solution was concentrated under reduced pressure. The crude product was purified using column chromatography on silica-gel. The fraction was eluted with hexane/ethyl acetate $=6 / 1$ afforded YK11 (2) $(1.26 \mathrm{~g}, 74 \%)$ as a mixture of diastereomers (ratio $=12: 1)$. Initially, we examined the recrystallization from hexane/ethyl acetate, and YK11 (2) (451 mg, 17:1) was obtained. Subsequently, the mixture (451 mg, 17:1) was separated through flash chromatography on silica-gel $(100 \mathrm{~g}$, hexane/ethyl acetate $=6 / 1)$. A total of 50 fractions were collected (F1-F20 216 mg, 10:1; F21-F30 149 mg, 52:1; F31-F50 48 mg, 100:1). Recrystallization (hexane/ethyl acetate) of F31-F50 yielded a single crystal of YK11 (2a). Colorless needles. Mp; $136^{\circ} \mathrm{C}$ (Hexane); $[\alpha]_{\mathrm{D}}^{25}=-104.0\left(\mathrm{c} 0.33, \mathrm{CHCl}_{3}\right)$; spectral data were identical with those reported in the literature [3].

\section{Conclusions}

The major diastereomer of YK11 (2) was prepared by palladium catalyzed diastereoselective cyclization carbonylation of $\mathbf{1}$. The structure of the major diastereomer $\mathbf{2 a}$ was determined by $\mathrm{X}$-ray crystallographic analysis. ARE-luciferase reporter assay in HEK293 cells suggested that the active constituent of YK11 was 2a. Although YK11 is sold via the internet as an anabolic steroid, it is an experimental drug candidate and a non-approved substance for humans [10-12]. It should be noted that YK11 has not been studied in humans or even animals.

Supplementary Materials: Luciferase reporter assay, crystallographic parameters for the structures of $2 a^{2}{ }^{1} \mathrm{HNMR}$ and ${ }^{13} \mathrm{C}$ NMR are available online.

Author Contributions: Conceptualization, K.K. and Y.K.; methodology, K.K. and Y.K.; X-ray analysis, S.K. and I.A.; investigation, T.K., K.T. and N.S.; writing - original draft preparation, K.K. and Y.K.; writing-review and editing, K.K. and Y.K.; supervision, K.K. and K.N.; project administration, K.K. and K.N. All authors have read and agreed to the published version of the manuscript.

Funding: This research received no external funding.

Conflicts of Interest: The author declares no conflict of interest.

\section{References}

1. Bhasin, S.; Jasuja, R. Selective androgen receptor modulators as function promoting therapies. Curr. Opin. Clin. Nutr. Metab. Care 2009, 12, 232-240. [CrossRef] [PubMed]

2. Narayanan, R.; Mohler, M.L.; Bohl, C.E.; Miller, D.D.; Dalton, J.T. Selective Androgen Receptor Modulators (SARMs) as Function Promoting Therapies. Nucl. Recept. Signal. 2008, 6, e010.

3. Kanno, Y.; Hikosaka, R.; Zhang, S.; Inoue, Y.; Nakahama, T.; Kato, K.; Yamaguchi, A.; Tominaga, N.; Kohra, S.; Arizono, K.; et al. (17a,20E)-17,20-[(1-Methoxyethylidene)bis(oxy)]-3-oxo-19-norpregna-4,20-diene-21-carboxylic Acid Methyl Ester (YK11) Is a Partial Agonist of the Androgen Receptor. Biol. Pharm. Bull. 2011, 34, 318-323. [CrossRef] [PubMed]

4. Yatsu, T.; Kusakabe, T.; Kato, K.; Inouye, Y.; Nemoto, K.; Kanno, Y. Selective Androgen Receptor Modulator, YK11, Up-Regulates Osteoblastic Proliferation and Differentiation in MC3T3-E1 Cells. Biol. Pharm. Bull. 2018, 41, 394-398. [CrossRef] [PubMed] 
5. Kato, K.; Nouchi, H.; Ishikura, K.; Takaishi, S.; Motodate, S.; Tanaka, H.; Okudaira, K.; TMochida, R.; Nishigaki, K.; Shigenobu, H.; et al. Facile Access to Spiro Furanone Skeleton Based on Pd(II)-Mediated Cyclization-Carbonylation of Propargylic Ester. Tetrahedron 2006, 62, 2545-2554. [CrossRef]

6. Ito, Y.; Kusakabe, T.; Dhage, Y.D.; Takahashi, K.; Sakata, K.; Sasai, H.; Kato, K. Total Synthesis of (-)-Graminin A Based on Asymmetric Cyclization Carbonylation of Propargyl Acetate. J. Org. Chem. 2019, 84, 16268-16277. [CrossRef] [PubMed]

7. Kusakabe, T.; Mochida, T.; Ariyama, T.; Lee, D.; Ohkubo, S.; Takahashi, K.; Kato, K. Pd ${ }^{\mathrm{II}}$ catalyzed ligand controlled synthesis of bis(3-furanyl)methanones and methyl 3-furancarboxylates. Org. Biomol. Chem. 2019, 17, 6860-6865. [CrossRef] [PubMed]

8. The Crystallographic Data (CCDC-1974030) can be Obtained Free of Charge from the Cambridge Crystallographic Data Centre. Available online: www.ccdc.cam.ac.uk/data_request/cif (accessed on 7 April 2020).

9. Ammann, S.E.; Liu, W.; White, M.C. Enantioselective Allylic C-HOxidation of Terminal Olefins to Isochromans by Palladium(II)/Chiral Sulfoxide Catalysis. Angew. Chem. Int. Ed. 2016, 55, 9571-9575. [CrossRef] [PubMed]

10. Piper, T.; Dib, J.; Putz, M.; Fusshöller, G.; Pop, V.; Lagojda, A.; Kuehne, D.; Geyer, H.; Schänzer, W.; Thevis, M. Studies on the in vivo metabolism of the SARM YK11: Identification and characterization of metabolites potentially useful for doping controls. Drug Test Anal. 2018, 10, 1646-1656. [CrossRef] [PubMed]

11. Thevis, M.; Piper, T.; Dib, J.; Lagojda, A.; Kühne, D.; Lars, P.; Geyer, H.; Schänzer, W. Mass spectrometric characterization of the selective androgen receptor modulator (SARM) YK-11 for doping control purposes. Rapid Commun. Mass Spectrom. 2017, 31, 1175-1183. [CrossRef] [PubMed]

12. Thevis, M.; Walpurgis, K.; Thomas, A. Analytical Approaches in Human Sports Drug Testing: Recent Advances, Challenges, and Solutions. Anal. Chem. 2020, 92, 506-523. [CrossRef] [PubMed]

(C) 2020 by the authors. Licensee MDPI, Basel, Switzerland. This article is an open access article distributed under the terms and conditions of the Creative Commons Attribution (CC BY) license (http://creativecommons.org/licenses/by/4.0/). 